\title{
ECOLOGICAL FEES AND TAXES IN POLAND AND THE NEW EUROSTAT INTERPRETATION
}

\begin{abstract}
This article tackles the issue of ecological fees and taxes in force in Poland in light of the new Eurostat interpretation. This is a consequence of the entry into force of new European Union rules, which oblige Member States to establish uniform reporting in this regard. Linked to this is the need to define and analyse the fees and taxes in force in Poland in terms of their compliance with the new rules, and to classify the various financial instruments (taxes, fees, etc.) as belonging to the ecological group. The author reviews and compares these instruments' definitions with the new Eurostat interpretation on the basis of Polish and foreign literature. The result is a juxtaposition of the ecological fees and taxes in force in Poland under the new Eurostat interpretation as well as a brief description of them.
\end{abstract}

Keywords: taxes, fees, environmental protection, statistical reporting.

\section{Introduction}

Ecological fees and taxes constitute an important instrument of ecological policy both in Poland and in the other European Union Member States. Their two major benefits are 1) that they serve to stimulate pro-ecological attitudes among households and economic entities and 2) that they generate money that can be allocated to the improvement of the environment. Interpreting them, however, has proved difficult. The European Union response took the form of Regulation (EU) no 691/2011 of the European Parliament and of the Council of 6 July 2011 on European environmental economic accounts (Regulation 2011). By virtue of this regulation the member countries of the EU, including Poland, are obliged to maintain "environmental economic accounts" and to report the data to the European Union's statistical office, Eurostat. 
Environmental economic accounts are prepared in three modules. One of these modules discussed in this paper is "a module for environmentally-related taxes by economic activity", in which, in accordance with the new interpretation of Eurostat, ecological fees are included in taxes connected with the environment. There is a requirement to report the sum attributable to "environmentally-related taxes" to Eurostat in dedicated reporting tables. These taxes are classified into four main categories which correspond to the four categories of tax bases: energy, transport, environmental pollution, and natural resources.

There is thus a need to analyse, in terms of the regulation mentioned above and the new rules, the ecological fees and taxes that are now required to be paid in Poland. To this end, the article aims to critically analyse the definition of "ecological fees" and "ecological taxes", and to examine the assignment of different varieties of fees and taxes to environmental categories. The author will, in addition, set out his own proposals with regard to these questions, which accommodate both the new Eurostat requirements and the specifics of the Polish case.

\section{Ecological Fees and Taxes under the Previous Dispensation}

Ecological fees and taxes are generally defined as specific financial loads placed on economic entities and households levied in terms of their relationship to the natural environment and their negative impact on it, which is understood both as pollution of the environment and also as the use of its resources.

It should be noted that, especially in the Polish literature ${ }^{1}$, a clear distinction is made between ecological fees and taxes. In the majority of cases, though, the foreign literature ${ }^{2}$ either treats both instruments as very similar or makes no distinction between them. In truth, it is often very difficult to differentiate between them. Though analogies may be drawn between these instruments and categories well known from theories of public finance, their scope, character and features are quite different. What is more, they can in some cases perform identical functions, but not on the same scale. When compared with other types of fees and taxes they may, for example, be designed to perform more of an incentive function than an income-generating one.

\footnotetext{
${ }^{1}$ See, for instance, Fiedor (2002a).

${ }^{2}$ See, for instance, Barde (1996).
} 
The greatest challenge to interpretation lies in understanding the decision to designate an instrument as pro-ecological, which leads on to the question of the relationship between the tax or fee and environmental harm or nuisance and, if such a relationship exists, to the question of its extent. A third question arises as a consequence of the first and second, which asks what degree of relationship - from harm to environmental nuisance should exist as a sufficient condition to cause a tax or fee to be regarded as ecological. These controversies stem mainly from the definition of these instruments, which is a necessarily complex matter where an impact on the environment exists but the relationship cannot be clearly quantified.

Let us now turn to the domestic and foreign academic literature for definitions of ecological taxes and ecological fees. In some cases a clear distinction is made and separate definitions are given. In others there is a single, common definition for taxes and fees related to the environment.

A number of different definitions of ecological taxes may be found in the environmental economics literature and in the reports compiled by international institutions. Bogusław Fiedor, for example, describes them as: "economic instruments for environmental protection that are levied on the emission of substances harmful to the environment or for usage that aggravates an environmental good" (Fiedor 2002a, p. 294), while in Żylicz's view ecological taxes are of a kind that: "should favour widely-understood environmental protection" (Żylicz 1995, p. 115). Eurostat, though, drawing on a slightly older mode of interpretation, defines such a tax as a kind of monetary provision whose base is a natural unit (or its equivalent) of a certain phenomenon or activity that generates a demonstrable impact, and especially a negative one, on the environment. It was decided to include all taxes on energy and transport in the definition of environmental taxes, but value-added taxes were excluded from the definition because of their specific character (Eurostat 2001, p. 9). In the OECD reports, an eco-tax is defined as any compulsory unrequited (non-returnable) payment to general government levied on tax bases deemed to be of particular environmental relevance (OECD 2001, p. 16), while in the European Environment Agency (EEA) studies an eco-tax is defined as one whose base is a physical unit of something that has a proven, defined and negative impact on the environment (European Environment Agency 2005, p. 41).

We thus see that the tax base, or subject, is all that distinguishes ecological taxes from other taxes. In that the proceeds of ecological taxes may be transferred to central or local budgets, their actual destination, and purpose of introduction, might have no relationship to environmental protection. 
The author of the present article would therefore suggest the following definition. Ecological taxes are financial loads whose proceeds are generally transferred to the central budget. They are levied by public authorities without counter-provision and the subject of the taxation is a phenomenon, activity or thing, such as gas emissions into the air, the use of natural resources or a plastic bag, that has a negative impact on the environment.

Arriving at a satisfactory definition appears simpler in the case of ecological fees. At the risk of simplification, it might be assumed that an ecological fee is a type of public fee that has a clear relationship with the natural environment. Some of the more complex definitions to be found in the academic literature restrict the definition to "fees for the use of the environment" and describe them as: "recompense for loss of environmental resources cause by economic activity, activated when the economic use of the environment proceeds according to binding rules and does not infringe standards. If the intensity of the disadvantageous impact on the environment is exceeded, a high financial penalty is applied instead of fees" (Brzeziński 1996, p. 161). Barde has offered a definition according to which ecological fees are "payments for each unit of pollution introduced to the environment, or for each unit of environmental damage incurred in exchange for a certain kind of service (for example: the use of municipal sewerage)" (Barde 1996, p. 229). Turning to the international institutions, the EEA has defined ecological fees as an obligatory and financial provision levied in favour of national or external institutions, such as Poland's National Fund for Environmental Protection and Water Management, for items such as sewage discharge or waste storage (European Environment Agency 2005, p. 16). The OECD, meanwhile, has defined them as requited (reversible) payments in favour of a government levied more or less in proportion to services provided. This could, for example, involve waste collection and treatment or the taking of surface water (OECD 2001, p. 16).

The author of the present article regards an ecological fee as a financial load of a not-fully-equivalent nature, which is collected in exchange for the use of natural resources, such as air, water and the earth's surface, and for the use of environmental values, and which is administered and collected by central or local public authorities.

It is worth emphasising that in the case of ecological fees, as opposed to ecological or environmental taxes, the services are provided by the state in return for being able to benefit from the environment. In this way, for example, a very clear distinction between ecological fees and taxes was made in an EEA report from the beginning of the last decade (European 
Environment Agency 2000, p. 19). The assertion that compulsory charges collected by the state in exchange for providing services related to the environment should be deemed ecological fees (duties) would appear to be correct, although the value of those services should be similar to fees paid (OECD 2006, p. 26). In this reading an ecological fee resembles a public charge; its collection is closely related to the provision of services. In the case of environmental services, though, which we may understand as the opportunity to benefit from natural resources and environmental goods, the direct service provider is not, as it is in the case of other services for which charges are collected, the state. It can be assumed that environmental services are provided by the natural environment itself as a constituent element of the national wealth. Here, the state is only a "representative" of the environment and its resources.

While many scholarly accounts have either given very distinct definitions distinguishing between ecological fees and taxes, or have been more content to highlight their similarities, one particular line of enquiry has contended that the concepts of ecological fees and ecological taxes are identical. Barde, for example, has claimed that payment for any unit of contamination or damage introduced to the environment can be called a charge or tax on pollution. If it is supposed that pollution emission might be measured with reasonable precision, this payment is easy to impose (Barde 1996, p. 229). As, however, he makes some distinction between these two instruments in the footnote, he is not entirely consistent in his interpretation. In another view, the payments for each unit introduced to the environment, or for each unit of environmental damage, are considered as ecological charges and taxes (Famielec 2000, p. 69). To take a third argument, Fiedor has stated that: "ecological fees and taxes entail differentiated forms of financial loads collected by economic subjects in return for the use of the resources and goods (material or nonmaterial) of the natural environment" (Fiedor 2002 b, p. 299). Finally, there have also been unpublished explorations of the field that have produced unified definitions of both instruments. One of these (Famielec (ed.) 2003, p. 12) claims that ecological fees and taxes are financial loads that are:

- the result of the direct introduction of contamination into the environment (e.g. gas emission and dust fees),

- related directly to products whose creation and use cause environmental pollution (e.g. production charges),

- the result of benefitting from environmental resources and services (e.g. fees for surface and groundwater intake). 
The EEA ${ }^{3}$, whose most frequently used terms for the instruments have been "eco-fees" and "eco-taxes", has also provided a definition of ecological fees and taxes (European Environment Agency 2000, p. 19) that does not distinguish too sharply between them. Nevertheless, the study did draw a distinction between them by reference to whether there was provision of a service by the state, so that the payer could benefit from the environment (eco-fees), or whether the state was not providing a service that entitled the payer to a benefit of this sort (eco-taxes). Since there is considerable fluidity surrounding this distinction, the European Union's flexibility with regard to national accounts categorisation should be acknowledged. It might be assumed from the above that there is little difference between ecological fees and taxes - other than that the former generate more benefit for the payer. In some cases ecological fees and taxes are understood together as specific ecological "levies". A more recent EEA report states that this term is a more general designation that includes taxes, fees and other similar tax loads. We are then informed that it remains in frequent use and the example of the United Kingdom (climate change levy, aggregates levy) is adduced. The use of "levy" can be at least partly attributed to the desire to avoid the negative connotation and social opposition associated with the word "tax" (European Environment Agency 2005, p. 41). The final term we need to be familiar with is "environmentally-related taxation", which is the one used by the OECD (OECD 2010, p. 33). It refers to any compulsory, unrequited (non-returnable) payment to general government that is considered to be of particular relevance to the environment.

The author likewise proposes a common definition for both categories. In this understanding, ecological fees and taxes are payments for each unit of:

- pollution introduced to the environment,

- environmental damage,

- exploitation of natural resources,

- utilisation (in production or consumption) of environmentally-harmful products.

The opinions we have rehearsed in this paper have not, including in their common definitions, made a convincing distinction between ecological taxes and fees that would allow us to decide whether a given instrument is pro-ecological, not pro-ecological or somewhat pro-ecological. Furthermore, if an instrument is pro-ecological, is it a tax or a fee? There have been significant differences in the way scholars have understood the differences

${ }^{3}$ More recent EEA studies contain many of these categories, cf. European Environment Agency (2005). 
between these categories. B. Fiedor, for example, has argued that ecological taxes differ from ecological fees in that the public incomes they generate can be identified as a general budget inflow. For this reason, unlike income from pollution fees, they do not have to be earmarked for accomplishing environmental-protection objectives (Fiedor 2002a, p. 294).

\section{Ecological Fees and Taxes in Force in Poland}

Based on the definitions of ecological fees and taxes previously adduced, we may state that a significant number of compulsory instruments of this kind are in force in Poland. The great majority of them are ecological fees, while there are only a few ecological taxes. The latter, though, raise an income that is many times higher than that from the former.

Therefore, in the light of the definitions we have established, and of the comparisons made in the comprehensive treatments of ecological fees and taxes in the Polish research literature ${ }^{4}$, fees for the following should be regarded as being in force in Poland:

- gas and dust emissions,

- surface and groundwater intake,

- waste storage,

- packaging, lubricating oil, tyres, batteries and accumulators,

- production of electrical and electronic equipment,

- bush and tree removal,

- concessionary and exploitive mining,

- the use of buildings and land connected with water administration (fees for the use of inland waterways and water facilities, fees for the use of certain bodies of water, fishing and angling fees, data-access and administration fees in respect of the water registry),

- emissions trading,

- fees payable when applying for integrated permission,

- the absence of a system for the collection of end-of-life vehicles,

- ozone-depleting substances,

- replacement payments for failing to buy the required amount of renewable energy,

- charges and fees for forest and agricultural land damaged by production,

- write-downs on the value of timber sales.

Ignoring for the moment possible questions of interpretation, the following items could be added to this list: vehicle registration and

I $\quad{ }^{4}$ Principally Bartniczak and Ptak (2011) and Małecki (2012). 
information fees, fuel fees, fees connected with some of the ecological fees mentioned above and additional taxes.

Two groups of ecological fees are usually defined: fees for use of the environment (the first four items on the list above) and all other ecological fees. Their number has grown in recent years, as new items that attract fees, such as ozone-depleting substances and the absence of a system for the collection of end-of-life vehicles, have been added.

It should be strongly emphasised that almost all of the proceeds from these fees go to the National Fund for Environmental Protection and Water Management as well as provincial environmental protection and water management funds. They mainly support investment in the amelioration of environmental degradation caused by production and other activities.

The following ecological financial loads that include the word "tax" in their names (but omit the preceding adjective "ecological") are in force in Poland: excise tax levied on environmentally-harmful consumption goods, tax on means of transport, forestry tax, agricultural tax, and a tax on extraction from some mines, which was introduced in 2012. The environmentally-harmful products subject to tax include electrical energy, all fuels, and passenger cars. Almost all of the proceeds from these taxes are transferred to the central budget or to local budgets.

\section{Ecological Taxes and Fees according to Eurostat's New Interpretation}

As a result of a new interpretation proposed by Eurostat, the term "environmentally-related taxes" (French: taxes liées à l'environnement), whose definition embraces ecological fees, has predominated in studies produced by international institutions for some time now. It adopts a single category for all financial loads (taxes, fees, surcharges, debts, levies) borne by economic entities, by other organisations and by households in connection with the environment. Eurostat (2013, p. 8) defines an environmentally-related tax as: "A tax whose tax base is a physical unit (or a proxy of a physical unit) of something that has a proven, specific negative impact on the environment, and which is identified in ESA as a tax". It is very significant here that this tax has to be considered a tax according to the European System of National and Regional Accounts (at present ESA 95). This system defines a tax as an obligatory and non-returnable financial load in cash or other form levied by government institutions, self-government institutions, or other European Union Institutions. Eurostat applies a broad interpretation to the term "environmentally-related taxes" which thus includes fees and other, similar 
financial loads (fees, charges, levies). In essence, though, the application of a fee or other similar load rests on a subject's proven, specific negative impact on the environment.

Against the background of the Eurostat construction, some questions of interpretation arose when compiling the list of environmentally-related fees in force in Poland. The most significant was that of including fees for waste storage, which is a fee for the use of the environment, and for concessions and exploitation in mining. In the Eurostat reading, these cannot be considered as environmentally-related taxes because they are acknowledged as a particular kind of rent derived from resources. Meanwhile, they have been acknowledged unequivocally as ecological financial loads in previous Polish interpretations, including those of this author. The argument is reinforced when we remember that the proceeds from fees applied to waste storage, refuse collection and mining are, in the main, transferred to funds for environmental protection. The Eurostat assumptions would also suggest that the category of environmentally-related taxes should include customs duties for imported fuels and related substances, and customs duties for imported vehicles, aircraft, and floating storage units. Until now, customs duties for environmentally-harmful products have not been regarded as ecological taxes in the Polish academic literature on environmental economics.

Based on an analysis of the new interpretations and requirements of Eurostat as set out in its latest guide to environmental taxes (Eurostat 2013), the author proposes a list of environmental fees, environmental taxes and other financial charges that are mandatory in Poland. The underlying argument is that compulsory ecological fees play a specific role in Poland. As a consequence, the proposals concerning the group related to the environment are justified. According to the Eurostat definition, the pro-ecological financial charges included on the list could be included in the category of environmentally-related taxes. This is set out in Table 1, which compares the environmentally-related taxes in force in Poland in light of Eurostat 2013 with the list of ecological taxes and fees from the previous dispensation (Bartniczak \& Ptak 2011; Małecki 2012). As may be appreciated, there are only a few cases in which the list resulting from the recent Polish interpretation differs from the new Eurostat list.

The left-hand column of Table 1 contains the final list of environmentally-related taxes in force in Poland - according to the Eurostat interpretation. A brief characterisation of each is given below. 
Excise tax on environmentally-harmful products

The category of environmentally-harmful products covered by excise tax covers all types of fuels destined for combustion and driving, LPG gas, lubricating oils, electrical energy and passenger cars. The rates of excise are decided according to environmental impact and all economic subjects active in these product areas are liable. The proceeds from the tax go to the state budget, while the administrative bodies involved are the Customs Offices and Customs Chambers. The taxpayers are obliged to pay their tax into the bank account of the relevant regional Customs Chamber.

\section{Tax on means of transport}

This is applied to trucks, tractors and ballast, trailers and semi-trailers, and buses. The rates applied, which are defined by local authorities, depend on the size of the vehicle and sometimes also on environmental impact. This tax is levied on owners of means of transport (natural and legal persons) and the sums due are paid into the bank account of the relevant local authority office.

Table 1. Ecological Taxes and Fees Regarded as "Environmentally-related Taxes" in Force in Poland according to the Latest Eurostat Interpretation and in Light of Previous Interpretations

\begin{tabular}{l|l}
\hline \multicolumn{1}{c|}{ Eurostat Interpretation } & \multicolumn{1}{c}{ Previous Findings $^{\mathrm{a}}$} \\
\hline Fuel excise & Fuel excise \\
\hline Electrical energy excise & Electrical energy excise \\
\hline Passenger car excise & Passenger car excise \\
\hline Lubricating oil excise & \multicolumn{1}{c}{-} \\
\hline Means of transport tax & Means of transport tax \\
\hline \multicolumn{1}{c}{-} & Agricultural tax \\
\hline $\begin{array}{l}\text { Customs duties for imported mineral } \\
\text { fuels, mineral oils and associated distilled } \\
\text { products, bituminous substances, and } \\
\text { mineral waxes }\end{array}$ & Forestry tax \\
\hline $\begin{array}{l}\text { Customs duties for imported vehicles, } \\
\text { aircraft, and floating storage units }\end{array}$ & \\
\hline Fees for gas and dust emissions into the air & Fees for gas and dust emissions into the air \\
\hline Fees for surface and groundwater intake & Fees for surface and groundwater intake \\
\hline
\end{tabular}


Table 1 cnt'd

\begin{tabular}{|c|c|}
\hline Eurostat Interpretation & Previous Findings $^{\mathrm{a}}$ \\
\hline $\begin{array}{l}\text { Fees for sewage discharge to surface and } \\
\text { groundwater }\end{array}$ & $\begin{array}{l}\text { Fees for sewage discharge to surface and } \\
\text { groundwater }\end{array}$ \\
\hline- & Waste storage fees \\
\hline $\begin{array}{l}\text { Fees for packaging, lubricating oil, tyres, } \\
\text { batteries, and accumulators }\end{array}$ & $\begin{array}{l}\text { Fees for packaging, lubricating oil, tyres, } \\
\text { batteries, and accumulators }\end{array}$ \\
\hline $\begin{array}{l}\text { Fees for the production of electrical and } \\
\text { electronic equipment }\end{array}$ & $\begin{array}{l}\text { Fees for the production of electrical and } \\
\text { electronic equipment }\end{array}$ \\
\hline Fees for the removal of bushes and trees & Fees for the removal of bushes and trees \\
\hline $\begin{array}{l}\text { Fees for the absence of a system for the } \\
\text { collection of end-of-life vehicles }\end{array}$ & $\begin{array}{l}\text { Fees for the absence of a system for the } \\
\text { collection of end-of-life vehicles }\end{array}$ \\
\hline- & $\begin{array}{l}\text { Fees for concessionary and exploitive } \\
\text { mining }\end{array}$ \\
\hline- & $\begin{array}{l}\text { Fees for the use of buildings and land } \\
\text { connected with water administration }\end{array}$ \\
\hline- & Fees for emissions trading \\
\hline- & $\begin{array}{l}\text { Fees payable when applying for integrated } \\
\text { permission }\end{array}$ \\
\hline Fees for ozone-depleting substances & Fees for ozone-depleting substances \\
\hline $\begin{array}{l}\text { Replacement fees for failing to buy the } \\
\text { required amount of renewable energy }\end{array}$ & $\begin{array}{l}\text { Replacement fees for failing to buy the } \\
\text { required amount of renewable energy }\end{array}$ \\
\hline Vehicle registration and information fees & - \\
\hline Fuel fees & - \\
\hline- & $\begin{array}{l}\text { Charges and fees for agricultural land } \\
\text { damaged by production }\end{array}$ \\
\hline- & $\begin{array}{l}\text { Charges and fees for forest land damaged by } \\
\text { production }\end{array}$ \\
\hline- & Write-downs on the value of timber sales \\
\hline Increased and additional fees & Increased and additional fees \\
\hline
\end{tabular}

Customs fees for environmentally-harmful products

Customs fees for environmentally-harmful products are applied to two groups. The first embraces mineral fuels, mineral oils and associated distilled products, bituminous substances and mineral waxes, and the second imported vehicles, aircraft, floating storage units and their associated 
transport installations. The fees are paid by importers and the proceeds go to the state budget. The taxes are administered by the Customs Offices and Customs Chambers.

\section{Fees for gas and dust emissions}

These fees are administered in the same way as the other environmental fees. Fees for gas and dust emission are applied to 67 volatile substances. The level of the fee depends on the type and amount of a volatile substance introduced into the air. The rates vary according to environmental impact. Fees for gas and dust emission into the air are also levied where no direct measurement of their type or amount is possible. This refers to emissions from small boiler rooms (with a nominal thermal power equal to $5 \mathrm{MW}$ ), to fuel combustion in internal combustion engines, to emissions released when reloading engine petrol and to the raising and breeding of poultry.

\section{Fees for surface and groundwater intake}

Fees for the collection of surface and groundwater are calculated and transferred in the same way, and are liable to be paid by the same individuals or entities, as other charges for the use of the environment. There is also an additional, variable charge for surface and groundwater intake that depends on the purpose of the water intake, its quality and the part of the country it is in, which are all factors that influence the level of fees set.

\section{Fees for sewage discharge to surface and groundwater}

Fees for sewage discharge to surface and groundwater fall into the category of fees for the use of the environment, which also includes charges made for surface and groundwater intake and for gas and dust emission. They are levied on all people and economic entities (the latter form the majority) that take advantage of environmental resources for production and other activities. The entities and people are themselves responsible for calculating the fees and transferring them to the Marshal's Office in the relevant province. The final beneficiaries of the proceeds are the National Fund for Environmental Protection and Water Management and district, and town and city, budgets. The following are regarded as sewage and are thus subject to fees for discharge to surface and groundwater: water used for economic or domestic purposes, animal liquid excrement, rainwater or snowmelt, water leaching from landfills, seawater, medicinal and thermal water coming from drainage facilities, mining discharges, wastewater discharged from rearing facilities or from fish farms and wastewater 
discharged from other aquatic organisms. The calculation of the amount of fees for wastewater discharge is complex and depends on the type and quantity of substances contained in wastewater, the type of treatment and, in the case of cooling water, the temperature. Fees for wastewater discharge are calculated based on four indicators for substances contained in the wastewater: five-day biochemical oxygen demand (BOD 5), chemical oxygen demand (COD), total suspended solids and total chlorides and sulphates.

\section{Fees for packaging, lubricating oil, tyres, batteries, and accumulators}

The payment-for-production system in force in Poland entails the obligation to reuse, recycle and collect some of the waste. Businesses selling products on the Polish market that are packaged in plastic, aluminium, steel, paper, cardboard, glass and wood, and those selling environmentally harmful products, such as batteries and accumulators, lubricating oils and tyres, must meet annual levels of recovery and recycling of waste from product packaging and from consumed products. Producers are liable to a product fee if this obligation is not met in full or is only partly met. The businesses calculate the product fee to be paid themselves and transfer it to the account of the Marshal's Office in the relevant province. The bulk of the proceeds go to the National Fund for Environmental Protection and Water Management.

\section{Fees for the production of electrical and electronic equipment}

There are only two differences between the rules for product fees for electrical and electronic equipment and those for packaging, lubricating oil, tyres, batteries and accumulators. The first is that rates for waste collection are applied for the production of electrical and electronic equipment. The second is that the businesses transfer the sums due to the National Fund for Environmental Protection and Water Management via the provincial funds for environmental protection and water management.

\section{Fees for the removal of bushes and trees}

Fees for the removal of bushes and trees must be paid by all owners who remove bushes or trees. The rates vary depending on the type and thickness of the tree trunk. In most cases, the fees are calculated by the mayor, who is the competent authority for the issuing of permits to remove bushes or trees, and not the owner of the property. There are a number of redundancies in the system for the regulation and administration of fees due for the removal 
of bushes and trees. Payments are made to the account of the municipal office in the relevant territory.

Fees for the absence of a system for the collection of end-of-life vehicles

Fees for the absence of a system for the collection of end-of-life vehicles are levied mainly on economic entitles (manufacturers, importers) who introduce motor vehicles to the Polish market. If this involves more than one-thousand vehicles per year, the entities are obliged to provide a system for the collection of end-of-life vehicles. They are liable for a fee if they do not do so. This obligation is also applied to natural persons importing motor vehicles from abroad for their own needs. The entire proceeds from these fees go to the National Fund for Environmental Protection and Water Management.

\section{Fees for ozone-depleting substances}

Fees for ozone-depleting substances are incurred by entities introducing them to the Polish market for the first time. This mainly applies to two groups of substances: hydrochlorofluorocarbons (HCFCs) and chlorofluorocarbons (CFCs). The entities required to pay it calculate the level of the fee themselves and make the payment to the account of the relevant Marshal's office. Almost the entire proceeds are transferred to the account of the National Fund for Environmental Protection and Water Management.

\section{Replacement fees for failing to buy the required amount of renewable energy}

Replacement fees for failing to buy the required amount of renewable energy stem from the need for a proportion of national consumption of electrical energy to be produced from renewable sources. In certain cases, companies that manufacture and trade in electricity will be liable for the fees. This is the case where a company has not provided the President of the Energy Regulatory Office with evidence that its certificates of origin (green certificates), which confirm that energy is generated from renewable sources, have been redeemed. The proceeds from these fees go entirely to the National Fund for Environmental Protection and Water Management.

\section{Vehicle registration and information fees}

Fees for vehicle registration and information are collected when registering vehicles. They cover the costs of registration certificates, 
temporary permits, validated license plates and monitoring stickers. All vehicle registration and information fees are paid to, and received by, the relevant local authority district.

\section{Fuel fees}

Fuel fees cover the introduction to the Polish market of motor fuels and gas used to power vehicles. The obligation to pay rests with producers and importers of motor fuels or gas, as well as with entities involved in intra-community acquisition (the movement of crude oil, petroleum products or natural gas from the territory of an EU Member State into the territory of the Republic of Poland). Eighty per cent of the proceeds go to the National Road Fund for construction, repair and maintenance, while the remaining $20 \%$ is transferred to the Railway Fund.

\section{Increased and additional fees}

Increased fees are levied for use of the environment where entities that benefit from the environment do not have the required permits or decisions regarding sewage disposal, water intake and gas and dust emission. The proceeds are disposed of in the same way as they are for basic charges. Additional fees, however, are generally incurred where entities have not paid the ecological fee in question within the specified period or where they have paid less than the total sum due. Additional fees are applied in connection with fees for production, for the absence of a system for the collection of end-of-life vehicles and for ozone-depleting substances. Almost the entire proceeds from increased and additional fees go to the National Fund for Environmental Protection and Water Management.

\section{Conclusions}

The European Union's new requirements for more uniform treatment of categories of ecological taxes and fees, and for the reporting of the funds derived from them to Eurostat, represent an interesting field of research. Until now, Polish interpretations of it, particularly with regard to the definition of ecological taxes and fees, but also to the classification of various fiscal and quasi-fiscal duties as belonging to the ecological group, have not been in full accord with Eurostat's designation of all environmentally-related financial loads as "environmentally-related taxes". This term subsumes ecological taxes and fees, as well as other similar financial loads, while Polish academic literature clearly demarcates both instruments. Take, for 
example, the fees for waste storage and mining in force in Poland, neither of which would be considered as taxes associated with the environment in the new Eurostat interpretation. On the other hand, customs duties on some imported environmentally-harmful products that were not hitherto considered as ecological fees should now be regarded as such. The majority of the many other ecological fees and taxes in force in Poland may be considered as taxes associated with the environment within the terms of the Eurostat interpretation.

\section{Bibliography}

Barde, J. Ph. (1996) "Polityka ochrony środowiska i jej instrumenty" [Environmental protection policy and its instruments] in H. Folmer, L. Gabel and H. Opschoor (eds) Ekonomia środowiska i zasobów naturalnych [The economics of the environment and natural resources]. Warsaw: Krupski i S-ka.

Bartniczak, B. and Ptak, M. (2011) Optaty i podatki ekologiczne. Teoria i praktyka [Ecological taxes and fees]. Wrocław: Wrocław University of Economics Press.

Brzeziński, B. (1996) Prawo podatkowe. Zarys wyktadu [Taxation law. Outline of a lecture]. Toruń: TNOiK "Dom Organizatora".

European Environment Agency (2000) Récents développements dans l'utilisation des écotaxes au sein de l'Union Européenne. Copenhagen: European Environment Agency, November.

European Environment Agency (2005) "Marked-based Instruments for Environmental Policy in Europe". EEA Technical Report No. 8/2005. Copenhagen: European Environment Agency.

Eurostat (2001) Environmental Taxes - A Statistical Guide. Luxembourg: Eurostat.

Eurostat (2013) Environmental Taxes - A Revised Statistical Guide 2013. Luxembourg: Eurostat, March.

Famielec, J. (2000) "Instrumenty polityki ekologicznej w krajach OECD” [Environmental policy instruments in OECD countries], Ekonomia i Środowisko 1(16).

Famielec, J. (ed.) (2003) Analiza bodźcowych podatków proekologicznych w wybranych krajach zachodnich i możliwość ich wprowadzenia w Polsce [Analysis of ecological tax incentives in selected western countries and the possibility of their introduction in Poland]. Kraków: Kraków University of Economics, Department of Industrial Policy and Ecology, February.

Fiedor, B. (2002a) "Instrumenty ekonomiczne - przegląd i kryteria wyboru" [Economic instruments - review and selection criteria] in B. Fiedor (ed.), S. Czaja, A. Graczyk and Z. Jakubczyk Podstawy ekonomii środowiska i zasobów naturalnych [Introduction to the economics of the environment and natural resources]. Warsaw: C. H. Beck.

Fiedor, B. (2002b) Optaty ekologiczne - przeglad i kryteria wyboru [Ecological fees - review and selection criteria] in B. Fiedor (ed.), S. Czaja, A. Graczyk and Z. Jakubczyk Podstawy ekonomii środowiska i zasobów naturalnych [Introduction to the economics of the environment and natural resources]. Warsaw: C. H. Beck. 
Małecki, P. P. (2012) System optat i podatków ekologicznych $w$ Polsce na tle rozwiąań $w$ krajach OECD [The system of ecological taxes and fees in Poland compared to solutions in OECD countries]. Kraków: Kraków University of Economics Press.

OECD (2001) Les taxes liées à l'environnement dans les pays d'OCDE. Problèmes et stratégies. Paris: OECD.

OECD (2006) L'économie politique des taxes liées à l'environnement. Paris: OECD.

OECD (2010) Taxation, Innovation, and the Environment. Paris: OECD.

Regulation (2011) "Regulation no 691/2011 of the European Parliament and of the Council of 6 July 2011 on European environmental economic accounts". Official Journal of the European Union L 192/1.

Żylicz, T. (1995) “Czy podatek może być ekologiczny?" [Can a tax be ecological?]. Cztowiek i Przyroda 3.

\section{Abstract}

\section{Oplaty i podatki ekologiczne w Polsce a nowe interpretacje Eurostatu}

W artykule podjęto zagadnienie opłat i podatków ekologicznych obowiązujących w Polsce w świetle nowych interpretacji Eurostatu. Są one konsekwencją wejścia w życie nowych regulacji Unii Europejskiej, które wprowadzają obowiązek tworzenia jednolitej sprawozdawczości w tym zakresie dla krajów członkowskich. Wiąże się z tym konieczność przeanalizowania, uznawanych w literaturze przedmiotu za ekologiczne, opłat i podatków obowiązujących w Polsce pod kątem zgodności z nowymi zasadami. Chodzi przede wszystkim o ich definiowanie, jak też zaliczanie poszczególnych instrumentów finansowych (podatków, opłat itp.) do grupy ekologicznych. W artykule dokonano przeglądu i porównania definicji tych instrumentów w polskiej i zagranicznej literaturze z nowymi interpretacjami Eurostatu. W efekcie przedstawiono zestawienie podatków i opłat ekologicznych obowiązujących w Polsce zgodnie z wykładnią Eurostatu oraz zaprezentowano ich krótką charakterystykę.

Słowa kluczowe: podatki, opłaty, ochrona środowiska, sprawozdawczość statystyczna. 